\section{p.16 原理的研究}

\section{1. 祭礼の本異としての Ludus（造战）と体青}

一Homo Ludens を中心に一

奈良女子大学大学院 村 岡 真

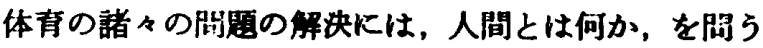

人間学が，本質的なかかわりをるつと思われるが，この 点で, Huizinga の “homo ludens”がてがかりにな る.彼は、この中で祭礼をとりあげ，祭礼の本貫が，游 歔と密接な閶係をわつこと，その祭礼を1つの手がかり としてとらえられる文化は，その根源においては，造找 されるすのであったこと、すなわち、文化は，遊战の中に (im Spiel) 一一遊戯として（als Spiel）発生し, 展硠 してきたとしている．彼ののべる遊戱怯，(1）自由で自 己日的们行為であること，(2）日常生活の利書には，直 接咲係しないこと，（3）完結性と限定性といら三つの要 素からなり，機能队には，表現 (Darstellung) と，周 争 (Kampt) のどちらかから学き出されるるのである. 彼は，この遊䖗を從来の遊线説とは異なり，文化の根源
として人間とのかかかりあいの中でながめ，科学では分

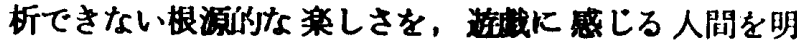
らかにしていこうとする。つまり，游阵の在から，

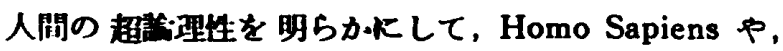
Homo Faber の根源化ある，新しい人間観 Homo Ludens を打ち出していくのである.

Huizinga は，現代の文化か，括戌性を失ないつつあ ることを，いいかえれば，人に Ludus が失なわれつつ あることを唋して，その誝を粘るのだが，体育も，現在 真の Ludus を失ないつつあるのではいか.

新しい人間学としての Homo Ludens の立場から， 文化を創造すべきである意味において，交化的性格をむ つた体直の本筫は，Ludus に求められなければならな い、いかえれば，体青の中に，遊阵性を回復しなければ ならないわけであるが, その味で, オリンピックや， スポーッ䋈典などの宗礼を，今一度考え直していくこと は重要である。

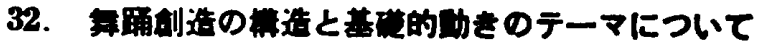
(その3）ーラパン・システムについて I長崎大学 堀牙三 郎

\section{研究目的}

教育舞踊に拈けるエホート概念の活用を考える前提と して，今回はラハンン・システムに四連する文融研究に上 り，エホートの全体的構造とその全般的応用分野につい てその具体例を検討し，舞踊の創造活软におけるエホー ト既念の応用についての指針を追求した。

\section{范}

1. エホートとは，あらゆる鸟体的行動に内在する蕉 本的・表現的力と考えられる.

2. ラハン・・システムにおいてい，私案の「舞踊創造 の構造」の中で「力要因」に当るものを「军䖝要因」と し，「力要因」の因子に当るむのを「エホート要美」と

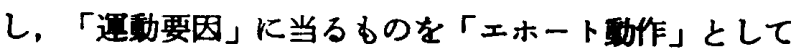
いる. しかし、これらのェホート動作は私案の「力要 因」の発展形として报らことる可能と考えられる.

3. エホート動作において，2つ以上の通峌要因から なる不完全エホートに一般门運動語を付けるのは困坓な 故に，その動作傎向とか内的能度のみが分類されてい る.

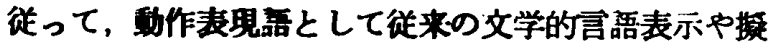
似的形容語を使用することは，㔙作個有の意味からずれ ることも多いから、基本的にはエホート的鱼善表示や部 号の使用は有协な手段の一つ考えられる.

4.エホート稳の庆用は, 身体を目的的に器具とし て用いたり，婄志伝逵の手段として用いる场合に有奻な 方法の一つであり，解ばかりでなく日常生活，労的作

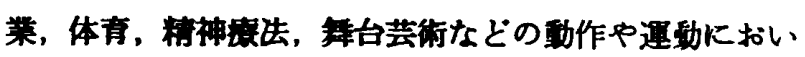
て広䉓に活用され得る。

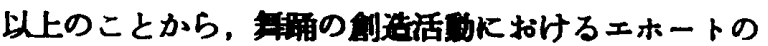
航今の店用は，単にある作品におけける特殊性格をつくり

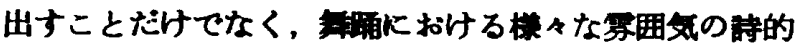

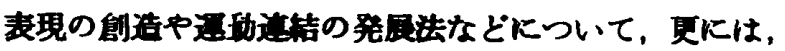

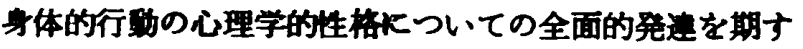
る目虰を助け得ると考えられる.すなわち，各人の偏。 たメホート㑯响を解消し，想攸的覚醒を伴って内的生活 を榓かにするように，エホート要因の全簀囲にわたる経 咉がなされなければならないと䒚える。 